\title{
'Come with me, sweetest sister': Unravelling the Enigma of Sacred Sisterhood in Aurora Leigh by Elizabeth Barrett Browning and “Goblin Market” by Christina Rossetti
}

\author{
Kayla Marie Penteliuk*
}

\begin{abstract}
Throughout the Victorian era, Elizabeth Barrett Browning and Christina Rossetti occupied a prominent position in a newly emerging female literary movement. Both authors sought to resist and revise the limitations of Victorian womanhood through the composition of controversial works that rivalled the achievements of their male contemporaries. In the 1856 epic Aurora Leigh by Elizabeth Barrett Browning and the 1862 narrative poem "Goblin Market" by Christina Rossetti, both Barrett Browning and Rossetti employ an early feminist perspective to explore the parameters of Victorian sisterhood and the potential strength of female friendship. Although Laura, Lizzie and Jeanie in Rossetti's work possess a sororal relationship that is distinct from Marian Erle and Aurora Leigh's relationship in Barrett Browning's work, the innumerable connections between both publications have caused critics to compare and hierarchize the two authors. Thus, a literary sisterhood has developed between Barrett Browning and Rossetti that curiously mirrors the sisterhoods of their fictions. This paper seeks to assess the inescapable presence of sisterhood in Aurora Leigh and "Goblin Market" by analyzing the manner in which a sisterly connection, not only through blood relations but also through close friendships that resemble sisterhood, allowed female forces to be allied, nurtured, and empowered amidst the patriarchal and misogynist structures of mid-nineteenth century Britain.
\end{abstract}

Keywords: Victorian England; nineteenth century; sisterhood; feminist theory; women writers

In an 1845 letter to Robert Browning, Elizabeth Barrett Browning describes Aurora Leigh as "a sort of novel poem...running into the midst of our conventions, and rushing into drawing rooms and the like, 'where angels fear

*Department of English, College of Arts and Science, University of Saskatchewan, Saskatoon, SK, Canada

Correspondence: kmp221@mail.usask.ca

University of Saskatchewan Undergraduate Research Journal Volume 4, Issue 2, 2018 
to tread'...meeting face to face and without mask the Humanity of the age, and speaking the truth as I conceive of it out plainly" (330). Both Aurora Leigh and "Goblin Market" by Christina Rossetti do rush into the stifled 'drawing rooms' of traditional Victorian literature and tempestuously rearrange the furniture of conventionality.

Aurora Leigh is a nine-book epic, situated hesitantly between different genres of poetry, Künstlerroman and Bildungsroman, and autobiography and fiction. Meanwhile, the disorderly iambic tetrameter of "Goblin Market" is situated precariously between children's literature and foreboding Sapphic verse. Yet Rossetti and Barrett Browning remain grounded in one powerful theme: the transcendent capacity of sisterly love. Although Laura and Lizzie in 'Goblin Market' are related by blood, Marian and Aurora in Aurora Leigh possess a friendship that merely resembles a biological bond. Nonetheless, sisterhood can be defined both as "a female in relationship to another person or persons having the same parents" and as "one who is reckoned as, or fills the place of a sister" ("sister"). Considering this definition, Laura and Lizzie in "Goblin Market" and Aurora and Marian in Aurora Leigh are presented as antithetical sisters: while one woman embodies darkness, evil, temptation, impure sexuality and infirmity, the other woman attempts to correct this problematic sinfulness with unconditional love, virginal purity and Christ-like forgiveness. Moreover, both poets reconstruct the conceptualization of sisterhood in a much more complex manner than the conventional definition allows: not only are Laura, Lizzie, Jeanie, Marian and Aurora representatives of a vehemently spiritual bond, but each pair of sisters also forms a distinctive community of selfsufficient motherhood. By subverting heterosexual convention through the unity of sisterhood, Barrett Browning and Rossetti explore the political implications of female sexual deviation through doubling, create a narrative that transforms mere sisterhood into an extraordinary maternal bond, and lastly, construct transcendent feminine worlds that often prioritize the power of sisterly love over patriarchal romance.

While the presence of sisterhood is conspicuous in "Goblin Market" because Laura, Lizzie, and Jeanie are at the forefront of the narrative, the emblematic relationship between Aurora Leigh and Marian Erle is easy to overlook in Aurora Leigh. Although Aurora and Marian do not end up looking dreamily into the sunrise of a New Jerusalem, the two women achieve a connection that resembles the heterosexual partnership of Romney and Aurora. Barrett Browning articulates this similarity when she writes that Romney "had to be blinded...to be made to see, just as Marian had to be dragged through the uttermost debasement of circumstances to arrive at the sentiment of personal dignity" ("Letters of Elizabeth Barrett Browning and Robert Browning on Aurora Leigh" 336). Whereas
Romney unsuccessfully attempts to traverse the class disparities surrounding him, his failure to perform this task contrasts with Marian and Aurora's success: as Angela Leighton says in her article, "'Because men made the laws': The Fallen Woman and the Woman Poet," the two women are "drawn to each other from a common bond of sexual powerlessness" (114) and thus, can move beyond the boundaries of social class to unite on equal terrain. In her book Elizabeth Barrett Browning: The Origins of a New Poetry, Dorothy Mermin explains that even though Aurora seems to be "baffled by the brute misery...hostility and violence" (203) of the lower classes, the unbreakable "sororal bond with Marian is deeper than the differences of class and education that circumscribe [their] friendship" (208). When Aurora seeks out Marian in the streets of Florence, she benevolently offers her companion "a home for you / And me and no one else" (Barrett Browning, Aurora Leigh 6.458-9) and forlornly expresses that she "lost [her] sister Marian many days, / And sought her ever in my walks and prayers, / And, now I find her" (6.449-51). Instead of seeking a surrogate mother or father to replace her longdeceased parents, Aurora finds an unexpected sister in Marian and attempts to recreate the loving, familial bonds of her childhood through this feminine communion. Most of all, Aurora resists the initial advances of Romney Leigh, along with his patriarchal conceptions of familial life, to prioritize the power of sisterly love.

Similarly, "Goblin Market" alludes to patriarchal structures through the persistence of the goblin men, but Rossetti's work purposefully transcends these motifs by introducing a remarkably bizarre and borderline erotic sisterly connection. Although Laura and Lizzie seem to be living in a stereotypical domestic utopia, making "kneaded cakes of whitest wheat / ... churned butter, whipped up cream" (205-7) and "sat and sew'd; / Talk'd as modest maidens should" (208-9), the reappearing motif of the fallen woman taints the perceived purity of these menial domestic chores. As soon as Laura gives in to the sexualized goblin men, she no longer wishes to fulfill her domestic duties as a subservient female protagonist: she

no more swept the house,

Tended the fowl or cows,

Fetched honey, kneaded cakes of wheat, [or] brought water from the brook. (293-6)

While Laura is adrift "in an absent dream" (211) due to her sickly longing for the goblin men's fruits, Jeanie is presented as the lost sister, as well as a representative of Laura's potential to become a fallen woman herself. In the dialogue between Lizzie and Laura, Rossetti constructs Lizzie as a model of virtuous purity through her prophetic reminders of Jeanie's reprehensible mistakes: 
Do you not remember Jeanie, How she met them in the moonlight, ...Sought them by night and day, Found them no more but dwindled and grew grey Then fell with the first snow[?] (147-57)

To remind Laura that she must resist the goblin men, Lizzie introduces Jeanie as a forbidden breach to the sacred parameters of sisterhood. Notably, in an acclaimed feminist study of Victorian women writers titled The Madwoman in the Attic: The Woman Writer and the Nineteenth-Century Literary Imagination, Sandra M. Gilbert and Susan Gubar argue that Jeanie is presented as "a witch or a madwoman, yielding herself entirely to an...unfeminine life of dream and inspiration... Her punishment, therefore, was that decline which was essentially an outer sign of her inner 'disease" (569). Subsequently, Lizzie must usher Laura into "a heaven of innocent domesticity" (566) to fix this "disease." Although Rossetti morbidly describes "Jeanie in her grave /... who for joys brides hope to have / Fell sick and died" (312-15), the lost sister maintains her significance by carrying a foreboding message to her surviving sisters. Thus, becoming a fallen woman is synonymous with a descent into madness, and this notion that Jeanie "should have been a bride" (313, emphasis added) indicates that a curiosity about sexual temptation is only tolerable within the conventional institution of marriage. In "Goblin Market," the sexually pure and morally upright sister assumes the duty of protecting the fallen sister from a deadly fate, and ultimately, Jeanie's seduction is described by Lizzie to convey the perils of female sexuality.

Although Aurora and Marian are not related by blood, the two women must learn how to navigate the unsteady terrain of sisterhood against the complex backdrop of Victorian sexuality, similar to Lizzie and Laura. At first, Aurora's interest in Marian is motivated by Lady Waldemar and her persistently vicious gossip; she harshly describes Marian as "a girl of doubtful life, undoubtful birth, / Starved out in London, till her coarse-grained hands / Are whiter than her morals" (Browning 3.535-7). However, when Aurora meets Marian, she does not "call [Romney's] choice unworthy" (3.538), as Lady Waldemar predicts. In fact, her opinion of Romney's working-class bride-to-be transforms completely:

She touched me with her face and with her voice, This daughter of the people. Such soft flowers, From such rough roots? the people, under there, Can sin so, curse so, look so, smell so... faugh!

Yet have such daughters? (3.805-9)

In a subsequent encounter where Aurora reunites with Marian in the streets of Italy, Aurora notices that Marian is carrying a small child. At first, Aurora conjectures that
Marian has been unchastely seduced by a man due to her aforementioned 'rough roots,' therefore leading to the birth of an illegitimate child (6.343-355). Following a heated confrontation between the two women, Marian accuses Aurora of thinking that she is "wicked" (6.740) and confesses that she "was not ever...seduced, / But simply, murdered" (6.770-1), implying that the fornication was not consensual. Shortly after this realization, Aurora immediately reverts to calling Marian "holy" (6.782) and clings "with woman's passion...about [Marian's] waist ...kiss[ing] her hair and eyes" (6.779-80). In a matter of moments, the unbreakable sororal bond between Aurora and Marian is established and thus, Marian is seemingly excused from her sin. Marjorie Stone adds that in this moment, Marian becomes "the necessary angel of the earth who redeems Aurora by reminding her of her own humanity....and leads her toward the revelation of a new order based not on purity, but on love" (Women Writers 1834). As opposed to the obvious transformation of Laura from fallen woman to redeemed sister in "Goblin Market," Marian and Aurora are both transformed through sisterhood, and Marian is uplifted to an almost implausible position of noble virtue. Elizabeth Barrett Browning articulates this transformation in a letter to her actual sister, Arabella Barrett:

I wanted a horrible situation to prove a beautiful verity. The intention of the poem everywhere is to raise the spiritual above the natural...Marian, subjected to the most hideous of trials, in fact though with an unconsenting will, is made to emerge with a glory of purity and even of moral dignity...you shall feel the virtue of chastity, in her, more even than in Aurora. (334)

Arguably, the sisterhood dynamic between Aurora and Marian possesses a more candid quality than the bond between Laura and Lizzie, but the common transformation from a fallen woman to a chaste sister in both "Goblin Market" and Aurora Leigh share tantamount similarities. Each pair of sisters transforms a "horrible situation" into a "beautiful verity," simply through the determination of one sister to remove the other sister from reprehensible circumstance.

While Marian is eventually redeemed for the birth of her illegitimate child and exceeds to a saint-like position in the narrative, Laura is vilified for her choice to accept the overtly sexualized fruit from the goblin men. In her article "'There is no friend like a sister': Sisterhood as Sexual Difference," Helena Michie draws attention to the fact that "the temptation of fruit [in "Goblin Market"] is...the temptation of difference, of sexual knowledge and the knowledge of difference" (415). Indeed, Laura temporarily wishes to separate herself from the sameness of sisterhood 
by rebelliously "choos[ing] to linger / Wondering at each merchant man" (Rossetti 69-70), despite Lizzie's warning of the "evil gifts" (66) that goblin men possess. When Laura sinfully stares at the goblin men and allows herself to carefully observe how "one had a cat's face, / One whisked a tail" (71-2), Michie notes that Laura begins to gain a sense of agency that exists outside of the safety of sisterhood (416): in fact, through her gradual recognition of the individuality of each 'one' of the goblin men, Laura realizes that she too is capable of achieving a distinct selfhood through the curiosity of sexual temptation (416). Following the acquisition of this autonomy, Lizzie seeks to transform Laura back into a mirror-image of herself: indeed, when the two women are described as lying "golden head by golden head, /...Cheek to cheek and breast to breast / Locked together in one nest" (Rossetti 184-98) it becomes impossible to ignore the homogeneity of the relationship. Rossetti implies that the true nature of sisterhood lies in the ability of both women to bond over their experiences; she writes that "tender Lizzie could not bear / To watch her sister's cankerous care, / Yet not to share" (299-301, emphasis added). Through the symbolic doubling of the two women, Rossetti can emphasize the disastrous consequences of breaking away from the paradigm of "sisterly sameness" (Michie 414) and restore Laura to a state of redeemed virtue.

Although Aurora and Marian do not share the physical similarities of Lizzie and Laura, the two women experience sisterly doubling through their romantic involvement with Romney Leigh. Moments after Marian declares, "I do not love you, Romney Leigh" (Browning, Aurora Leigh 9.355) and flees, Aurora bravely confesses her true feelings for Romney, hesitantly saying, "I love, - / I love you, Romney" (9.607-8). Because Marian immediately rejects Romney's second proposal of marriage, Aurora is quickly propelled toward a future of marital bliss with her cousin as a result of this rejection. Perhaps Aurora acts as a sororal replacement by accepting Romney's hand in the absence of Marian. Evidently, shortly after confessing that she does not love Romney, Marian turns to Aurora and pleadingly says, "catch my hands, / Miss Leigh, and burn into my eyes with yours, I I swear I do not love him. Did I once?" (9.356-8). In this passage, Marian is both seeking affirmation from Aurora and reassuring Aurora that she may pursue Romney if she wishes. In Between Women: Friendship, Desire, and Marriage in Victorian England, Sharon Marcus notes that even in the midst of a complex remarriage plot, Barrett Browning assures that sisterhood is at the helm of major matrimonial decisions: she says that "female friendship gives form to wedlock, and any subsequent union between Romney and Marian would only reproduce the bonds, gestures, and acts already performed between [Marian and Aurora]" (95). The compassionate female unity in Aurora Leigh makes marriage fathomable between Romney and Aurora.
Moreover, the restorative power of female friendship allows Marian to reject Romney and lead Aurora toward a future of marital bliss. At the end of Barrett Browning's novel-poem, Marian and Aurora achieve sisterly harmony by nearly becoming mirror images of one another, just as Laura and Lizzie are returned to a balanced state of sameness at the end of "Goblin Market."

Remarkably, in both "Goblin Market" and Aurora Leigh, the only way to attain complete restoration from sexual difference is to reestablish a sororal bond through the creation of a matriarchal household. Following Lizzie's brave sacrifice to recover the purity of her sister, Rossetti moves forward "days, weeks, months, years" (543) to an orderly domestic scene that portrays Lizzie and Laura as wives "with children of their own; / Their mother-hearts beset with fears" (545-46). However, Rossetti neglects to disclose the genders of "the little ones" (548) she describes; instead, Laura and Lizzie are

joining hands to little hands

[and] bid them cling together -

'For there is no friend like a sister

In calm or stormy weather. (560-3, emphasis added)

In the article "Heroic Sisterhood in 'Goblin Market,"' Dorothy Mermin notes that "Laura turns the encounter with the goblins into a tale told and retold as a ritual to bind the children together, and the moral she draws from it is not that girls should avoid goblins" (117); in fact, the moral of Rossetti's tale is that sisterhood will prevail, despite the looming threat of sexually devious goblin men. Laura and Lizzie implicitly reject the enticement of male eroticism in favour of multiple female bonds. Therefore, through the next generation of Lizzie and Laura's children, the power of sisterhood will continue to be reproduced and strengthened.

Similarly, in Aurora Leigh, Aurora graciously offers Marian both a home, a newfound sister, and a co-parent:

'Come with me, sweetest sister,' I returned,

'And sit within my house, and do me good

.... am lonely in the world,

And thou art lonely, and the child is half

An orphan. Come, - and henceforth, thou and I

Being still together will not miss a friend,

Nor he a father, since two mothers shall

Make that up to him.' (7.117-125)

Both Marian and Aurora must find solitude and support not only within each other but also within the comfort of a sisterly living arrangement, much like the matriarchy of Rossetti's sisters.

According to Marjorie Stone, the connection between Marian and Aurora demonstrates one of the many ways 
that Barrett Browning "de-centres masculine metaphors and myths... [and] transforms silent or marginalized women into speaking subjects" (Women Writers 13). Barrett Browning portrays sisterhood as the uniting force that pulls two dissimilar women into the same societal orbit and ultimately, allows Aurora and Marian to determine their fates as 'speaking subjects' in a narrative of their own construction. In Aurora and Marian's household, "two mothers" transcend the limitations of class to jointly raise a child and thus, create a haven of sisterly companionship outside the normality of heterosexual marriage.

Not only do "Goblin Market" and Aurora Leigh establish distinctive sisterhood narratives, but also, both Barrett Browning and Rossetti themselves possess a strange sororal connection. In a passage from her essay titled "Aurora Leigh," Virginia Woolf wryly articulates the unusual relationship between Elizabeth Barrett Browning and Christina Rossetti:

Fate has not been kind to Mrs. Browning as a writer. Nobody reads her, nobody discusses her, nobody troubles to put her in her place. One has only to compare her reputation with Christina Rossetti's to trace her decline... The only place in the mansion of literature that is assigned to [Barrett Browning] is downstairs in the servant's quarters, where...she bangs the crockery about and eats vast handfuls of peas on the point of her knife. (439)

Although Woolf is rather dramatic with her servant's quarters metaphor, she identifies an intriguing feature of Rossetti and Barrett Browning's historical relationship: in most accounts, both women are situated at odds with one another, as opposed to a recognition that each poet possesses her distinct vocation. To comprehend the relationship between Barrett Browning and Rossetti, some scholars have imagined a mother-daughter mentorship (Stone, "Sisters in Art" 341), speculating that Rossetti extracted the finest qualities of Barrett Browning's work to create her own poetic canon. Although this process of vocational revision may be true, the mother-daughter approach suggests a troublesome hierarchy that ultimately favours one artist over the other. In her article "Sisters in Art: Christina Rossetti and Elizabeth Barrett Browning," Marjorie Stone critiques the tendency of scholars to hierarchize female writers; she emphasizes that Rossetti and Barrett Browning should be referred to as "sisters in art" (341) with neither writer in a more prominent position than the other. Stone explains that the "tendency [to compare Rossetti to Barrett Browning] is troubling because it reinforces deeply ingrained cultural assumptions that there can only be one great woman writer among a particular group of writers" (359). Instead of creating an oppositional divide, Stone insists that the scholar must employ a didactic, comparative approach to Victorian women writers that engages both Rossetti and Barrett Browning equitably, thus, evading the temptation to make hierarchical classifications. In fact, when Rossetti was asked by John Ingram to write an essay on Barrett Browning, Rossetti confirmed that the two women had never even met: "I should write with enthusiasm of that great poetess and (I believe) lovable woman," she writes, "whom I was never...so fortunate as to meet" (qtd. in Stone, "Sisters in Art" 343). Remarkably, the dissonant comparisons between Rossetti and Barrett Browning closely resemble the antithetical sisterly relationships in "Goblin Market" and Aurora Leigh: in both poems, one sister is viewed as superior to the other.

Although she started out as a virtually unknown transatlantic contemporary to both Barrett Browning and Rossetti, Emily Dickinson drew much of her poetic inspiration from these two 'sisters in art'. Motivated by the revolutionary pathways that these British women were forging for writers all over the globe, the American poet likely wrote many poems with works such as Aurora Leigh and "Goblin Market" in the forefront of her mind. According to Betsy Erkkila in The Wicked Sisters: Women Poets, Literary History, and Discord, a framed portrait of Barrett Browning hung in Dickinson's bedroom and the developing poet "sought to create her own life in the images of the lives of the fictive heroines of Browning" (60-1). For many female writers in the nineteenth century, a sense of sisterhood could be established across oceans through the common creation of art. In an 1853 poem, Dickinson describes the Victorian perception of sisterhood:

One Sister have I in our house -

And one a hedge away.

There's only one recorded -

But both belong to me.

...She did not sing as we did -

It was a different tune -

Herself to her a music

As Bumble bee of June.

Today is far from Childhood,

But up and down the hills, I held her hand the tighter -

Which shortened all the miles -

...I chose this single star

From out the wide night's numbers -

Sue - forevermore! (21)

In the poem, Dickinson notes that she has a blood-related sister in her house, but the other sister possesses an 
abstract connection to her because she lives 'a hedge away, sings 'a different tune' and is 'chose[n]...from out the wide night's numbers.' Despite the different geographical locations of the three poets, Dickinson inadvertently conveys the transcendent power of sisterly love that constitutes the narrative backbone of "Goblin Market" and Aurora Leigh. In the nineteenth century and beyond, sisterhood possesses the ability to "shorten all the miles" of a long and arduous life. The remarkable connection between Elizabeth Barrett Browning and Christina Rossetti, both as literary 'sisters' in Victorian writing and as creators of extraordinary fictional sisters, demonstrates how female bonds act as a site of resistance and allow the marginalized Victorian spirit to flourish in the presence of sisterly companionship.

\section{Acknowledgements}

I would like to express my gratitude to Dr. Douglas Thorpe for his invaluable guidance and support as I pursued this topic. I would also like to dedicate this paper to the memory of the late Orest Bodnarchuk. My research would not exist without the tenacity for reading and boundless creativity that he cultivated within me throughout my formative years.

\section{Bibliography}

Barrett Browning, Elizabeth. Aurora Leigh. Aurora Leigh: Norton Critical Edition. $1^{\text {st }}$ ed., edited by Margaret Reynolds, W.W. Norton \& Company, 1996.

Barrett Browning, Elizabeth and Robert Browning. "Letters of Elizabeth Barrett Browning and Robert Browning on Aurora Leigh." Aurora Leigh: Norton Critical Edition. $1^{\text {st }}$ ed., edited by Margaret Reynolds, W.W. Norton \& Company, 1996, pp. 329-349.

Dickinson, Emily. "One Sister Have I in the House." The Poems of Emily Dickinson, edited by R. W. Franklin, Harvard UP, 2005, p. 21.

Erkkila, Betsy. The Wicked Sisters: Women Poets, Literary History, and Discord. Oxford UP, 1992.

Gilbert, Sandra, and Susan Gubar. The Madwoman in the Attic: The Woman Writer and the Nineteenth-Century Literary Imagination. Yale UP, 1979.

Leighton, Angela. "'Because Men Made the Laws': The Fallen Woman and the Woman Poet." Victorian Poetry, vol. 27, no. 2, 1989, pp. 109-127. JSTOR, www.jstor.org/stable/ 40002337.

Marcus, Sharon. Between Women: Friendship, Desire, and Marriage in Victorian England. Oxford UP, 2007. Mermin, Dorothy. Elizabeth Barrett Browning: Origins of a New Poetry. U of Chicago P, 1989.

--.. "Heroic Sisterhood in 'Goblin Market."' Victorian Poetry, vol. 21, no. 2, 1983, pp. 107-118. JSTOR, www.jstor.org/stable/40002024.

Michie, Helen. "'There Is No Friend Like a Sister': Sisterhood as Sexual Difference." ELH, vol. 56, no. 2, 1989, pp. 401-21. JSTOR, www.jstor.org/stable/2873065.

Rossetti, Christina. "Goblin Market." The Broadview Anthology of British Literature: The Victorian Era. ${ }^{\text {nd }}$ ed., vol. 5, edited by Joseph Black et. al., Broadview Press, 2012, pp. 546-53.

"sister, n." OED Online. Oxford University Press, June 2017. Accessed 28 Oct. 2017.

Stone, Marjorie. Women Writers: Elizabeth Barrett Browning. St. Martin's Press, 1995.

---. "Sisters in Art: Elizabeth Barrett Browning and Christina Rossetti." Victorian Poetry, vol. 32, no. 3/4, 1994, pp. 339-64. JSTOR, www.jstor.org/stable/40002822.

Woolf, Virginia. "Aurora Leigh." Aurora Leigh: Norton Critical Edition. $1^{\text {st }}$ ed., edited by Margaret Reynolds, W.W. Norton \& Company, 1996, pp. 439-446. 